\title{
Daily Intake of Kaempferia parviflora Extract Decreases Abdominal Fat in Overweight and Preobese Subjects: A Randomized, Double-Blind, Placebo-Controlled Clinical Study [Corrigendum]
}

Yoshino S, Awa R, Miyake Y, et al. Diabetes Metab Syndr Obes. 2018;11:447-458.

The authors have advised that there is an error in the note section of Table 5 on page 454 . The text in the Notes
"Values are presented as mean \pm SD" should read "Data are expressed as mean $\pm \mathrm{SD}$ for values or mean $\pm \mathrm{SE}$ for delta"

The authors apologize for this error.

\section{Publish your work in this journal}

Diabetes, Metabolic Syndrome and Obesity: Targets and Therapy is an international, peer-reviewed open-access journal committed to the rapid publication of the latest laboratory and clinical findings in the fields of diabetes, metabolic syndrome and obesity research. Original research, review, case reports, hypothesis formation, expert opinion and commentaries are all considered for publication. The manuscript management system is completely online and includes a very quick and fair peer-review system, which is all easy to use. Visit http://www.dovepress.com/testimonials.php to read real quotes from published authors. 